Original Research Paper

\title{
Penggunaan Mendeley dan Endnote dalam Menyisipkan Sitasi
}

\author{
Fitri Maya Puspita ${ }^{1}$, Sisca Octarina ${ }^{1}$, ${\text { Evi } \text { Yuliza }^{1}, \text { Indrawati }^{1} \text {, Ayu Wulandari }}^{1}$, Diyaz Rachmaningtyas ${ }^{1}$ \\ ${ }^{I}$ Jurusan Matematika, Fakultas MIPA, Universitas Sriwijaya, Indonesia
}

https://doi.org/10.29303/jpmpi.v3i2.598

Sitasi: Puspita, F. M., Octarina, S., Indrawati., Wulandari, A., \& Rachmaningtyas, D. (2021). Penggunaan Mendeley dan Endnote dalam Menyisipkan Sitasi . Jurnal Pengabdian Magister Pendidikan IPA, 4(1)

\author{
Article history \\ Received: 02 Desember 2020 \\ Revised: 29 Desember 2020 \\ Accepted: 22 Januari 2021 \\ *Corresponding Author: Sisca \\ Octarina, Jurusan Matematika, \\ Fakultas MIPA, Universitas \\ Sriwijaya, Indonesia. \\ Email: \\ sisca_octarina@unsri.ac.id
}

\begin{abstract}
Penulisan karya ilmiah bukan merupakan hal yang baru dalam dunia akademik. Karya ilmiah yang ditulis dapat berupa artikel, makalah, skripsi, tesis, disertasi, maupun jurnal. Penelitian pendukung, sumber teori, dan sumber bacaan sangat diperlukan dalam penulisan, sehingga jika ingin disadur atau disitasi dalam tulisan maka perlu ditulis sumbernya. Penulisan sitasi yang banyak memerlukan ketelitian dan waktu lebih, terutama dalam penyesuaian format penulisan. Hal ini menyebabkan diperlukannya software untuk menyisipkan sitasi. Mendeley dan EndNote adalah software yang dapat dipakai untuk menyisipkan sitasi dalam penulisan ilmiah. Permasalahannya banyak pengguna yang belum paham akan penggunaan kedua jenis software ini. Oleh karena itu, kegiatan pengabdian ini bertujuan untuk mengenalkan penggunaan Mendeley dan EndNote dalam menyisipkan sitasi. Kegiatan ini dilakukan secara daring menggunakan platform Zoom Meeting, dengan jumlah peserta 225 orang tersebar dari seluruh Indonesia. Hasil post-test menunjukkan terdapat peningkatan pemahaman sebesar $70 \%$ dari semua peserta dalam menerapkan penggunaan software Mendeley dan EndNote. Kegiatan ini sangat bermanfaat jika dilaksanakan secara lebih intensif kepada pelaku akademik.
\end{abstract}

Keywords: Karya Ilmiah; Mendeley; EndNote; Sitasi

\section{Pendahuluan}

Karya tulis ilmiah merupakan salah satu bentuk teknik penulisan yang dirancang untuk mengkomunikasikan informasi ilmiah kepada ilmuwan lain (Chotimah, 2009). Bergantung pada jenis penulisan ilmiah tertentu, artikel jurnal, poster ilmiah, atau proposal penelitian, misalnya beberapa aspek tulisan dapat berubah, seperti tujuan, audiens, atau organisasinya. Banyak aspek dari tulisan ilmiah yang berbeda di antara jenis tulisan ini.

Penulisan ilmiah tidak hanya sekedar menulis tentang sains. Penulisan tentang sains adalah tulisan teknis yang para ilmuwan lakukan untuk mengkomunikasikan penelitian mereka kepada orang lain (Syaefullah, 2015). Penulisan ilmiah didasarkan pada rumitnya penyelidikan ilmiah, sehingga harus mencerminkan ketelitian yang sama seperti yang dituntut dalam proses penelitian (Costanza et al., 2015). Komunikasi ilmiah menuntut ketepatan (penggunaan kata dan frasa yang tepat), kejelasan, dan ekonomis. Perbedaan ini penting karena penulis mengkomunikasikan informasi yang sangat teknis kepada orang lain yang mungkin, atau mungkin tidak berpengetahuan; mungkin dari disiplin ilmu yang berbeda; mungkin, atau mungkin tidak, menjadi penutur asli dari bahasa yang digunakan. Banyak jurnal memiliki khalayak internasional, jadi komunikasi yang tepat membantu mencegah kesalahpahaman dan kesalahan terjemahan dalam konteks lain. Mengkomunikasikan fakta, gambaran, dan metode yang digunakan dalam penelitian serta deskripsi hasil harus tepat.

Audiens utama dari sebuah tulisan ilmiah adalah ilmuwan lain. Karena audiens yang dituju, maka detail, definisi, dan penjelasan yang 
berorientasi pada siswa atau audiens umum, yang sering kali diperlukan dalam manual atau laporan menjadi tidak terlalu berguna (Lombardo, 2020). Menjelaskan konsep pengetahuan umum atau bagaimana prosedur rutin dilakukan sebenarnya cenderung tidak jelas, membuat tulisan bertele-tele, dan mengurangi gaya profesionalnya. Tujuan dari penulisan ilmiah ini adalah menyampaikan informasi ilmiah secara jelas dan ringkas.

Sumber penulisan seperti penelitian pendukung, sumber teori, dan sumber bacaan sangat diperlukan dalam penulisan, sehingga jika ingin disadur atau disitasi dalam tulisan maka perlu ditulis referensinya. Penulisan sitasi memerlukan ketelitian dan kerapian terutama dalam penyesuaian format penulisan. Sumber kutipan dapat berupa body note yang disertakan di dalam kalimat, atau berupa foot note yang diletakkan di bagian bawah halaman. Di halaman terakhir dibuat daftar sumber kutipan, yang sering diberi judul Daftar Pustaka atau Daftar Referensi. Penulisan sitasi secara manual memerlukan waktu dan ketelitian yang lebih. Terkadang ada beberapa kutipan yang lupa kita cantumkan di daftar pustaka atau daftar referensi. Ada beberapa referensi yang salah dalam sitasi tahunnya dan beragam kemungkinan kesalahan lainnya. Kita membutuhkan software untuk menyisipkan sitasi. Mendeley dan EndNote adalah software yang dapat dipakai untuk menyisipkan sitasi dalam penulisan ilmiah.

Mendeley adalah software manajemen sitasi dan referensi ke dalam sebuah jejaring sosial yang bisa membantu mengorganisir penelitian, berkolaraborasi dengan peneliti lain secara online dan menemukan publikasi penelitian terakhir (Bhoi, 2018). Fungsi mendeley adalah untuk membuat daftar pustaka dengan mudah dalam menyusun karya tulis ilmiah. Pengguna dapat menggunakan Mendeley sebagai sebuah aplikasi desktop yang terinstal secara offline di komputer. Aplikasi tersebut, sering disebut sebagai Mendeley Desktop. Selain itu, pengelolaan menggunakan Mendeley juga dapat dilakukan secara online (Mendeley Web).

Software kedua yang akan diperkenalkan pada kegiatan pengabdian ini adalah EndNote. EndNote adalah alat perangkat lunak multiplatform yang membantu dalam mengelola proses penulisan dan persiapan makalah penelitian (Woodward \& House, 2019). Kita bisa lebih fokus pada penulisan makalah yang sebenarnya jika kita membiarkan
EndNote melakukan pekerjaan sitasi. EndNote akan mengelola PDF dan file penelitian lainnya, secara otomatis mengumpulkan informasi penting dari file Anda untuk memudahkan referensi dan pembuatan kutipan. Selain menggunakan EndNote di ponsel cerdas, tablet, atau desktop, kita juga memiliki akses ke situs web EndNote, tempat kita dapat terhubung dengan sistem perpustakaan Universitas untuk mencari jutaan makalah penelitian dan artikel jurnal.

Permasalahan yang dihadapi adalah tidak semua orang pernah menggunakan kedua software ini ataupun paham akan penggunaannya. Melalui kegiatan pengabdian kepada masyarakat, tim pengabdian dari Jurusan Matematika Fakultas MIPA Universitas Sriwijaya menyelenggarakan kegiatan dalam bentuk webinar tentang pengenalan penggunaan Mendeley dan EndNote dalam menyisipkan sitasi. Kegiatan ini sangat bermanfaat jika dilaksanakan secara lebih intensif kepada pelaku akademik.

\section{Metode}

Penggunaan Mendeley dan EndNote dalam menyisipkan sitasi merupakan topik kegiatan pengabdian kepada masyarakat yang kami lakukan. Metode pelaksanaan secara daring dengan platform zoom dilaksanakan pada tanggal 16 Juli 2020. Peserta kegiatan adalah mahasiswa, dosen, guru, siswa SMA dan peserta umum dari seluruh Indonesia. Tahapan pelaksanaan yang kami lakukan adalah melaksanakan pre-test untuk mengukur tingkat kepahaman awal dari peserta. Setelah pretest, kegiatan dilakukan dengan memperkenalkan cara penggunaan Mendeley terlebih dahulu, kemudian dilanjutkan dengan tutotial. Pada sesi kedua dari pelaksanaan yaitu pengenalan penggunaan EndNote, yang juga dilanjutkan dengan pelaksanaan tutotialnya. Tingkat pemahaman peserta diukur berdasarkan nilai posttest yang diberikan kepada peserta.

\section{Hasil dan Pembahasan}

Kegiatan pengabdian ini dilakukan dalam dua sesi, dimana sesi pertama yaitu pengenalan Mendeley dan sesi kedua yaitu pengenalan EndNote. Tahapan pertama pada pelaksanaan kegiatan pengabdian ini adalah memberikan pretest kepada peserta. Hal ini dilakukan untuk 
menguji dan mengetahui kepahaman peserta sebelum mendapatkan materi dari narasumber. Kemudian dilanjutkan dengan memperkenalkan cara mengunduh dan menginstall Mendeley, yang diikuti oleh tutorial untuk praktek penggunaan bersama dengan peserta. Sesi kedua yaitu pengenalan dan tutorial penggunaan EndNote. Berikut materi Mendeley dan EndNote yang diperkenalkan pada kegiatan ini.

\section{a. Pengenalan Mendeley}

Langkah pertama yang dilakukan adalah mengenalkan cara mengunduh dan menginstall Mendeley. Berikut adalah langkah-langkah dalam mengunduh dan menginstall Mendeley:

1. Software dapat diunduh secara gratis melalui website www.mendeley.com

2. Pilih create a free account.

3. Masukkan alamat email, nama depan dan nama belakang.

4. Masukkan karakteristik pengguna. Isikan password, pilih bidang studi yang ditekuni dan status akademisnya.

5. Pilih Download Mendeley.

6. Jika file instalasi tidak terdownload secara otomatis maka klik restart the download.

7. Setelah selesai terdownload klik Run, tunggu sampai file selesai terinstalasi dan buka aplikasinya.

8. Pilih Log in to existing account dan pilih Continue.

9. Buka Mendeley. Perhatikan toolbar dan menubar yang muncul.

10.Klik Tools pada toolbar di aplikasi Mendeley dan pilih Install MS Word Plugin.

11. Buka dokumen pada Ms. Word dan pada toolbar muncul Reference.

Literature search akan membantu menemukan beberapa kata kunci dari literatur dan memberikan informasi dari bagian kata kunci tersebut. Pada kegiatan ini juga diajarkan cara membuat referensi. Caranya yaitu mengumpulkan file-file yang akan disimpan di Mendeley ke dalam satu folder untuk mempermudah pencarian. Semua referensi dapat disimpan dalam satu folder atau beberapa folder jika berbeda topik. Masukkan seluruh referensi yang ada satu-persatu, dengan menyeret file dari folder yang berisi kumpulankumpulan file dan menaruhnya di halaman Mendeley. Selanjutnya lengkapi data jurnal dengan mengisi kolom, Author, Year, Volume, Issue, Pages, Abstract, Tags, Author Keywords dan URL (sesuai data yang ada).

Cara membuat sitasi dan mengubah gaya penulisan sitasi juga dijelaskan. Untuk membuat sumber kutipan, dengan cara membuka file format word lalu klik References. Pilih insert citation dan Klik Go to Mendeley. Sedangkan cara mengubah gaya sitasi dengan cara berikut:

1. Klik kolom Style pada References.

2. Dapat dipilih style dari style yang telah diinstal.

3. Jika style tidak ada maka dapat dicek pada get more style.

4. Kemudian pilih done dan secara otomatis mengubah style pada dokumen word.

Penggabungan sitasi dilakukan dengan blok sitasi yang akan digabung kemudian klik Merge Citations. Daftar pustaka dibuat dengan cara mengklik insert bibliography pada References. Jangan mengedit dari MS Word karena apabila di klik Refresh maka perbaikan yang telah dilakukan akan sia-sia. Jika ingin mengedit maka edit file tersebut pada mendeley. Kembali lagi ke MS Word kemudian klik Refresh.

\section{b. Pengenalan EndNote}

EndNote adalah suatu paket perangkat lunak manajemen referensi komersial yang digunakan untuk mengelola bibliografi dan referensi saat menulis esai atau artikel. Fungsi EndNote yaitu untuk mengolah referensi, mengolah gambar, melacak referensi online, dan menyusun bibliografi manuskrip. Kegiatan pada sesi kedua ini dimulai dengan mengenalkan cara menginstalasi dan memulai EndNote. Adapun caranya adalah:

1. Akses https://endnote.com/downloads/30-daytrial/

2. Klik Run setup.exe

3. Setelah installasi selesai, maka EndNote akan terintegrasi dengan microsoft word.

4. Klik start menu/programs/endnote/endnote program.

Selain itu, pada sesi ini juga dijelaskan cara preview reference, penambahan style, menambahkan daftar referensi, menyisipkan artikel, membuat sitasi, mengubah gaya penulisan sitasi, dan membuat daftar pustaka atau daftar referensi.

Pelaksanaan kegiatan ini dilakukan pada tanggal 16 Juli 2020 secara daring dengan 
menggunakan platform zoom. Peserta kegiatan sebanyak 225 orang dengan latar belakang profesi sebagai mahasiswa, dosen, guru, siswa SMA dan peserta umum dari seluruh Indonesia. Hasil pre-test yang diberikan di awal kegiatan menunjukkan hanya sebanyak $40 \%$ dari total peserta yang mendapatkan nilai di atas 80 . Hal ini menyatakan bahwa masih rendah sekali pemahaman peserta akan penggunaan Mendeley dan EndNote.

Setelah pelaksanaan kegiatan dan tutotial, semua peserta akan diberikan post-test. Evaluasi hasil post-test menunjukkan terjadi peningkatan kepahaman peserta. Hal ini terlihat sebanyak $70 \%$ peserta yang mendapatkan nilai post-test di atas 80 . Walaupun pelaksanan kegiatan pengabdian ini secara daring, tetapi rekaman kegiatan juga kami rekam dan publikasikan melalui akun youtube pada link https://www.youtube.com/watch?v=azyC3F4 $\mathrm{XNM}$, sehingga dapat dengan mudah diakses dan ditonton kembali. Berikut diberikan beberapa foto pelaksanaan kegiatan.

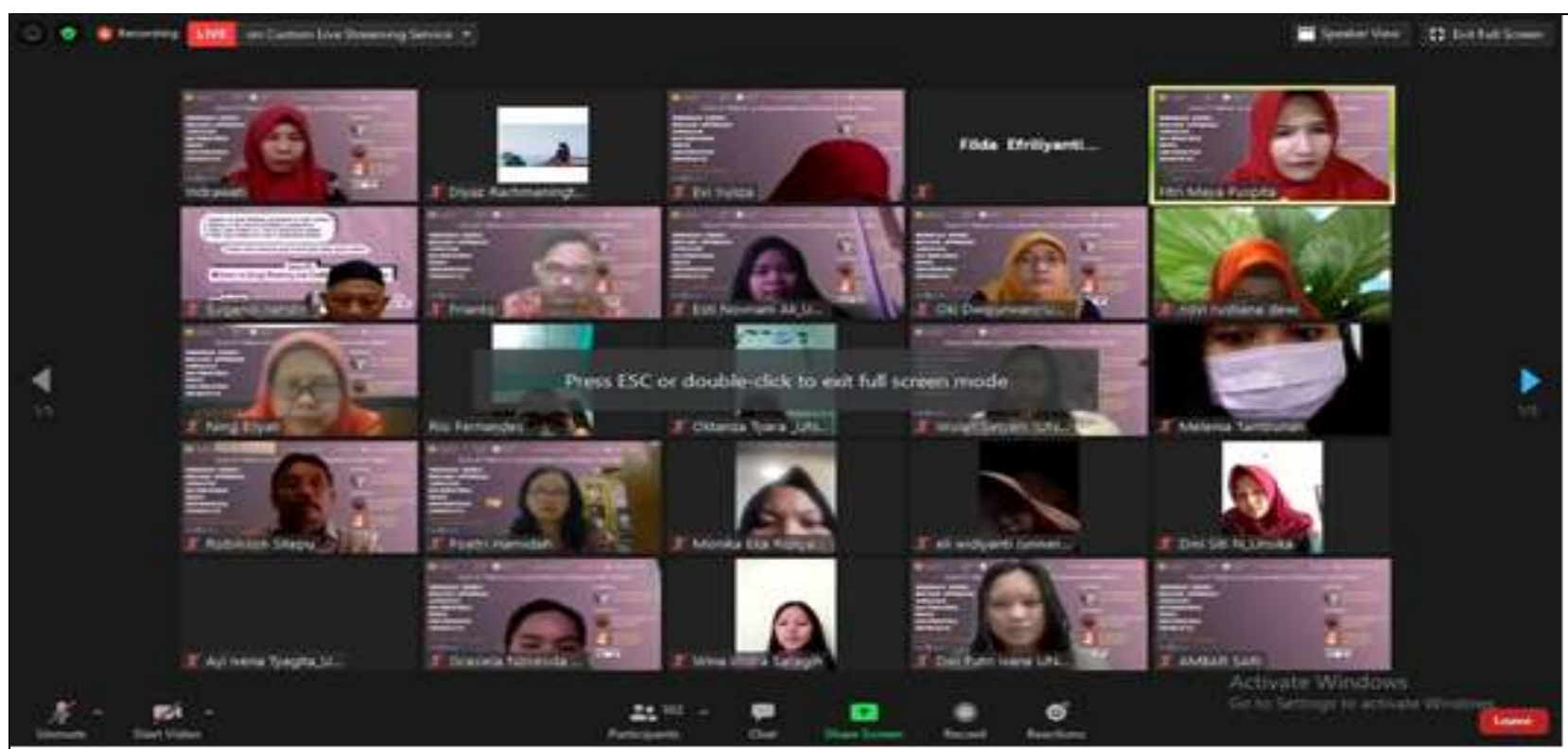

Gambar 1. Foto Pelaksanaan Kegiatan 1

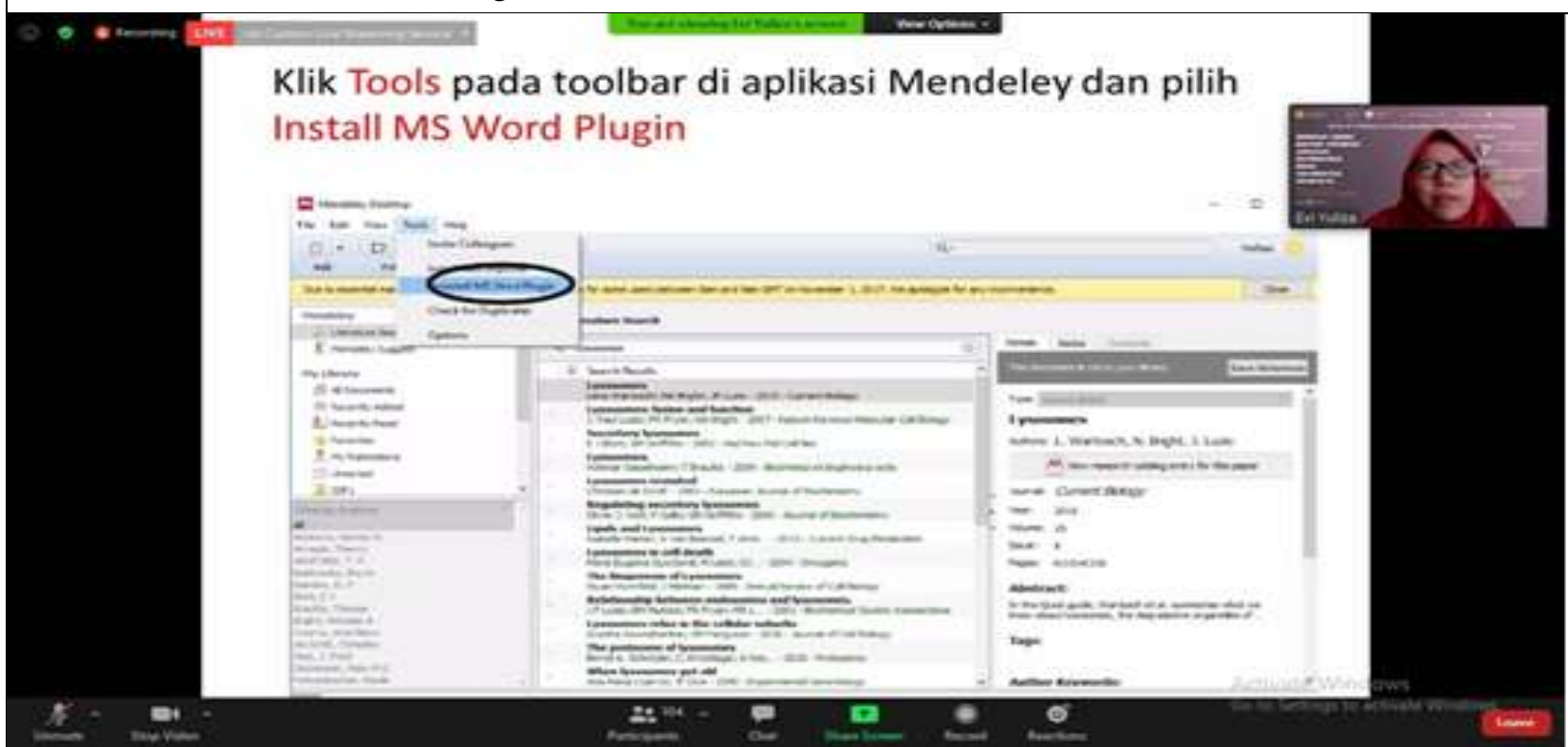

Gambar 2. Foto Pelaksanaan Kegiatan 2 


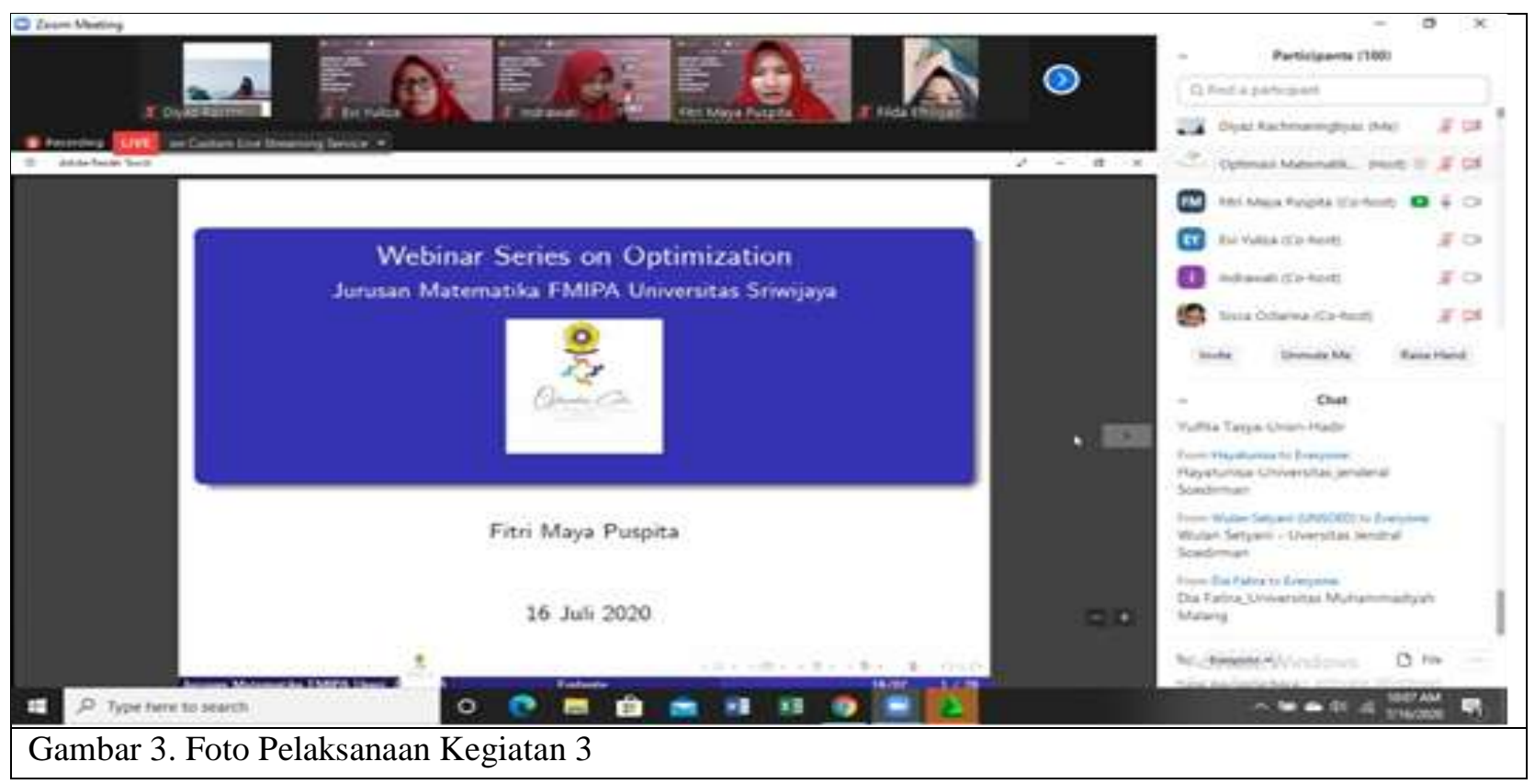

Semua peserta berperan aktif dalam pelaksanaan kegiatan. Hal ini ditunjukkan bahwa semua peserta mengikuti pre-test dan post-test. Tidak ditemukan kendala yang berarti pada saat pelaksanaan, karena didukung oleh jaringan

\section{Kesimpulan}

Kesimpulan yang dapat diambil dari kegiatan pengabdian ini adalah bahwa Mendeley dan EndNote merupakan software yang dapat dipakai untuk sitasi dan mudah dipahami. Kegiatan ini sangat bermanfaat untuk menambah pengetahuan akan cara penggunaan software dalam sitasi. Dikarenakan pelaksanaan secara daring, maka dapat diikuti oleh semua peserta dari berbagai daerah di Indonesia.

\section{Ucapan Terima Kasih}

Kegiatan pengabdian ini dapat berlangsung atas bantuan banyak pihak. Tim pelaksana menyampaikan ucapan terima kasih kepada Dekan Fakultas MIPA dan Ketua Jurusan Matematika Fakultas MIPA Universitas Sriwijaya yang telah mengizinkan pelaksanaan kegiatan ini, semua peserta kegiatan, dan anggota Tim Pengabdian yang telah mendukung dan mensukseskan kegiatan ini. internet yang kuat pada waktu pelaksanaan. Akan tetapi pelaksanaan kegiatan secara offline pasti akan jauh lebih baik karena dapat melalui tatap muka langsung antara narasumber dan peserta.

\section{Daftar Pustaka}

Bhoi, N.K. 2018. Mendeley Data Repository as a platform for Research Data Management. Marching Beyond Libraries: Managerial Skills and Technological Competencies, 481-487.

Chotimah, U. 2009. Karya tulis ilmiah sebagai salah satu karya pengembangan profesi guru. https://www.academia.edu/download/33134441 12._Makalah_Karya_Tulis_Ilmiah-UC.pdf diakses tanggal 25 Oktober 2020

Costanza, M., Maxwell, A., Wright, C., and Bertollini, M.E. 2015. What is Scientific Writing? https://sites.middlebury.edu/middsciwriting/ove rview/ diakses tanggal 27 November 2020

Lombardo, R. 2020. The Basics of Scientific Writing. https://www.unl.edu/gradstudies/connections/sc ientific-writing diakses tanggal 20 November 2020

Syaefullah, A. 2015. Prinsip Dasar Penyusunan \& Penulisan Karya Tulis Ilmiah. Grasindo.

Woodward, C. M. \& House, A. 2019. What is EndNote? https://www.dummies.com/education/what-isendnote/ diakses tanggal 25 November 2020 